\title{
KEBERFUNGSIAN SOSIAL BURUH PEREMPUAN PADA SEKTOR INDUSTRI DALAM KELUARGA
}

\author{
Oleh: \\ Dessy Fitri Pratiwi, Hadiyanto A. Rachim, \& Rudi Saprudin Darwis
}

Oleh;

(dessyfitri.pratiwi@gmail.com; hrachim@yahoo.co.id; rsdarwis@gmail.com)

\begin{abstract}
ABSTRAK
Partisipasi buruh perempuan dalam sektor industri telah menggeser komitmen sebagai ibu rumah tangga. Keterlibatan buruh perempuan di sektor industri tidak sedikitnya karena masalah ekonomi. Dalam hal ini buruh perempuan dihadapkan dengan dua tuntutan peran, yaitu sebagai ibu rumah tangga dan sebagai pencari nafkah yang menuntut kewajiban dan tanggung jawab dilakukan secara bersamaan. Adapun dilematis peran ganda yang buruh perempuan rasakan adalah perasaan bersalah kerap muncul manakala buruh perempuan dihadapkan pada situasi yang mengharuskan keberadaannya di tengah keluarga. Jam kerja yang panjang dan tidak teratur membuat buruh perempuan sulit mengatur tugas sebagai ibu rumah tangga. Karena sebagian besar waktu buruh perempuan adalah di tempat kerja untuk mengejar target produksi. Dilematis yang dirasakan buruh perempuan akan menimbulkan konflik-konflik yang cukup pelik dalam diri buruh perempuan maupun dalam keluarga. Tak jarang buruh perempuan mengalami emosi tidak stabil, stress, mudah marah, sering kelelahan dan gangguan kesehatan. Selain itu, tak jarang menimbulkan perselisihan dengan anggota keluarga, hilangnya komunikasi, serta disfungsionalitas dalam keluarga. Akibatnya keberfungsian sosial buruh perempuan dalam keluarga tidak dapat dilakukan secara efektif, sehingga akan menimbulkan permasalahan yang dapat mengurangi kualitas hidup buruh perempuan. Dalam hal ini pekerja sosial berperan untuk membantu buruh perempuan untuk dapat meningkatkan kemampuan buruh perempuan dalam menjalankan perannya, pemenuhan kebutuhan dasarnya, memperbaiki relasi buruh perempuan dengan anggota keluarganya, serta mampu mengatasi masalahnya dalam keluarga dengan cara memperbaiki komunikasi di antara anggota keluarga. Selain itu, kebijakan dari pemerintah maupun perusahaan mengenai jam kerja perlu dikaji kembali, khususnya untuk perempuan.

Kata kunci : faktor ekonomi, peran ganda, konflik, jam kerja, keberfungsian sosial.
\end{abstract}

\section{PENDAHULUAN}

Seiring dengan perubahan yang terjadi di masyarakat memicu seseorang untuk memperbaiki dan meningkatkan kualitas hidup. Tentu hal ini juga dilakukan oleh buruh perempuan di Indonesia yang berpartisipasi dalam sektor industri. Adapun data perempuan yang bekerja dalam sektor industri di Provinsi Jawa Barat adalah sebagai berikut :

Tabel 1.1 Penduduk Berumur 15 Tahun Keatas yang Bekerja Menurut Lapangan Usaha dan Jenis Kelamin di Provinsi Jawa Barat 2010

\section{Lapangan Usaha Laki- Perempuan \\ Laki}




$\begin{array}{lcc}\text { Pertanian / Agriculture } & 68,92 & 31,08 \\ \text { Industri / Manufactory } & 61,36 & 38,64 \\ \text { Perdagangan / Trade } & 60,24 & 39,76 \\ \text { Jasa-jasa / Services } & 60,88 & 39,12 \\ \text { Lainnya/ Other } & 92,63 & 7,37 \\ \text { Jumlah } & \mathbf{6 7 , 8 0} & \mathbf{3 2 , 2 0}\end{array}$

Sumber : Sakernas BPS Provinsi Jawa Barat (http://jabar.bps.go.id/publikasi_BPS/2013/inkesra2012/files/search/searchtext.xml diakses pada tanggal 1 Oktober 2014 pukul 07.05 WIB)

Berdasarkan tabel 1.1 bahwa buruh perempuan di sektor industri 38,64\% lebih rendah daripada jumlah buruh laki-laki di sektor industri $61,36 \%$.

Keterlibatan buruh perempuan di sektor industri tidak sedikitnya karena dorongan faktor kebutuhan ekonomi keluarga. Hal ini dikarenakan buruh perempuan rata-rata adalah perempuan golongan menengah ke bawah yang masih memiliki tingkat pendidikan dan keahlian yang rendah.Adapun penyebab rendahnya pendidikan adalah karena masyarakat miskin terbatas dalam mengakses layanan pendidikan karena tingginya beban biaya pendidikan (http://jitoum.blogspot.com/2009/05/permasalahan-kemiskinan.html diakses pada tanggal 2 Oktober 2014 pukul 17.15 WIB). Selain itu, adanya ketidaksetaraan gender dalam pendidikan dimana adanya perbedaan dalam hak dan kewajiban perempuan dan laki-laki dalam mengecap pendidikan formal (Suleeman, 1995). Adapun data tingkat pendidikan perempuan di Kabupaten Sumedang adalah sebagai berikut :

Tabel 1.2 Jumlah Penduduk Berdasarkan Tingkat Pendidikan dan Jenis Kelamin 2010

Tingkat Pendidikan

Tamat Perguruan Tinggi

Tamat SLTA

Tamat SLTP

Tamat SD

Tidak/Belum Tamat SD

\section{Laki-Laki Perempuan}

$19.483 \quad 16.879$

$87.302 \quad 69.876$

$87.205 \quad 84.082$

$185.045 \quad 205.358$

$13.527 \quad 17.677$

Sumber : BPS Kabupaten Sumedang, (http://www.benangmerah. net/place/idn/jawabarat/kabupaten-sumedang\# dataukpgoiddatasetjumlah-penduduk-15-tahun-ke-atas-yang-bekerja-perkabupaten.com diakses pada tanggal 6 November 2014 pukul 16.10 WIB)

Berdasarkan tabel 1.2 bahwa tingkat pendidikan perempuan lebih rendah dibanding tingkat pendidikan laki-laki.Hal ini ditandai dengan masih banyaknya perempuan yang tidak/belum tamat SD sebanyak 17.677 orang sedangkan jumlah laki-laki yang tidak/belum tamat SD sebanyak 13.527 orang.

Bagi perempuan yang sudah bekerja akan dihadapkan dengan dua tuntutan peran, yaitu sebagai ibu rumah tangga dan sebagai pencari nafkah. Kedua peran yang harus dimainkan oleh buruh perempuan membawa konsekuensi kewajiban dan tanggung jawab yang harus dilakukan secara bersamaan dan keduanya menuntut untuk dapat dilakukan secara optimal. Hal ini akan membawa dampak yang cukup dilematis pada buruh perempuan untuk dapat memfungsikan perannya sebagai ibu rumah tangga dan pekerja, sehingga akan menimbulkan konflik yang cukup pelik dalam diri buruh perempuan untuk dapat mengoptimalisasikan perannya tersebut (Ella, 2003:286).

Bentuk konflik yang dialami buruh perempuan biasanya terkait mengenai pekerjaan dan keluarga. Konflik pekerjaan terhadap keluarga terjadi saat pengalaman bekerja mempengaruhi kehidupan keluarga. Contohnya tekanan dalam lingkungan kerja, seperti jam kerja yang panjang dan tidak fleksibel, perjalanan yang jauh, beban kerja yang berlebihan, stress kerja, organisasi atau atasan yang tidak mendukung. Konflik keluarga terhadap pekerjaan terjadi saat pengalaman dalam keluarga 
mempengaruhi kehidupan kerja, seperti tekanan dalam keluarga, seperti hadirnya anak masih kecil, konflik diantara anggota keluarga, dan kurangnya dukungan dari keluarga.

Adapun konflik lain dalam diri buruh perempuan adalah perasaan bersalah yang kerap muncul manakala dihadapkan pada situasi yang mengharuskan keberadaannya di tengah keluarga pada saat dibutuhkan dengan kewajibannya pada pekerjaannya. Menurut Meyrs (1993) dalam Ella (2003:286287) bahwa apabila seseorang dihadapkan pada dua tuntutan harapan sesuai dengan perannya yang berbeda dan harus ditampilkan dalam waktu yang bersamaan, maka orang tersebut mengalami konflik. Konflik peran ganda yang dialami buruh perempuan adalah dia merasakan ketegangan ketika tidak mampu memenuhi tuntutan antara rumah tangga dan pekerjaannya.

Seseorang yang hidup tak lepas dari peran yang harus dijalani dalam perkembangan kehidupannya, demikian halnya juga dengan buruh perempuan. Dia memiliki peranan dalam keluarga, sebagai isteri dan ibu rumah tangga. Adapun peran istri dalam keluarga adalah sebagai pendamping suami, pendorong dan pembangkit suami, dan penerus keturunan. Sedangkan Ibu berperan merawat, mendidik dan membimbing putera puterinya menuju kedewasaan, memberikan peneladanan sesuai dengan norma dan nilai yang berlaku, sebagai teman bermain dan berbicara dari putera puterinya, mengatur dan mengurus rumah tangga, mengamati tingkah laku putera puterinya (Direktorat Keluarga, Jenderal Pemberdayaan Sosial, 2003:25).

Adapun persoalan yang kerap kali dihadapi oleh buruh perempuan adalah jam kerja. Seperti yang kita ketahui bahwa jam kerja buruh perempuan terbilang panjang dan tidak teratur, mulai pada pagi hari hingga sore hari atau tergantung pada keadaan jadwal masing-masing buruh. Hal ini diperkuat dengan pendapat Jumisih, selaku Ketua Forum Buruh Lintas Pabrik bahwa dia bekerja sebagai buruh selama 9 sampai 10 jam setiap harinya (http://m.rnw.nl/bahasa-Indonesia/ node/137853 diakses pada tanggal 4 Mei 2014 pukul $19.30 \mathrm{WIB})$. Padahal dalam Undang-Undang No 13 Tahun 2003 tentang Tenaga Kerja, jam kerja orang dewasa yang sesuai di Indonesia adalah 40 jam perminggu. Untuk keryawan yang bekerja 6 hari dalam seminggu sehingga terhitung 7 jam dalam 1 hari dan 40 jam dalam seminggu. Sedangkan untuk karyawan yang bekerja 5 hari dalam seminggu kewajiban bekerja mereka adalah 8 jam dalam 1 hari dan 40 jam dalam seminggu.

Menurut Mulyanto dalam Sumarsono (2009) tingkat pencurahan jam kerja adalah presentase banyaknya jam kerja yang dicurahkan terhadap jumlah jam kerja yang tersedia. Jam kerja dan pendapatan merupakan variabel yang sulit untuk dipisahkan. Pendapatan/upah diperoleh seseorang dari suatu pekerjaan melalui pencurahan jam kerja untuk bekerja yang menghasilkan barang dan jasa. Hal itulah yang membuat buruh perempuan lebih banyak menghabiskan waktu di tempat kerja karena mengejar target produksi perusahaan, di mana target produksi mempengaruhi besar kecilnya upah yang didapat.

Dalam studi kasus buruh perempuan di KBN Cakung yang banyak menitipkan anaknya kepada orang lain sebelum memulai bekerja. Hal ini dikarenakan perusahaan tidak mengizinkan karyawannya untuk membawa anak serta dikhawatirkan mengganggu konsentrasi dan kinerja mereka. Adapun data hasil penelitian dari Lembaga Analisis kebijakan dan Advokasi Perburuhan bahwa seribu buruh perempuan yang diteliti, semuanya telah berkeluarga dan memiliki satu orang anak. Sebanyak seribu anak dari buruh perempuan, 970 anak diantaranya dititipkan di kampung halaman untuk diasuh sanak keluarga. Sedangkan 30 orang anak buruh perempuan yang berusia bayi, pengasuhannya dititipkan kepada warga setempat atau tetangganya (http://m.hukumonline. com/berita/baca/lt51ca80df50bad/anak-anak-pekerja-butuh-perhatian diakses pada tanggal 4 Mei 2014 pukul $20.00 \mathrm{WIB})$.

Salah satu contoh yang menunjukkan indikasi akan terganggunya keberfungsian sosial buruh perempuan adalah adanya pengaruh perubahan peran yang dialami buruh perempuan terhadap keharmonisan keluarga. Adapun hasil penelitian yang menunjukkan bahwa hubungan isteri yang bekerja dengan tingkat harmonisasi keluarga, terjadi melalui tingkat pendapatan isteri. Dalam arti bahwa jika isteri yang bekerja tersebut pendapatannya dapat untuk mencukupi seluruh kebutuhan 
keluarga, maka disfungsional bagi urusan-urusan kerumahtanggaan, ketergantungan ekonomis kepada suaminya menjadi rendah, sikap kemandirian isteri menjadi tinggi, sehingga tingkat harmonisasi keluarga dapat menjadi goyah, meskipun seluruh kebutuhan ekonomi keluarga relatif dapat tercukupi. (Nurhadi, Muflich. 2009:52).

Hasil penelitian Muflich Nurhadi menunjukkan bahwa 36,6\% suami menyatakan isteri sebenarnya lebih pas untuk mengurusi urusan-urusan rumah tangga dan 26,66 \% suami menyatakan bahwa sebaiknya seorang istri memang tidak usah mencari nafkah, tetapi mendidik dan mengurusi anak-anak di rumah. Selain itu, presentase yang kurang lebih sama 23,33\% suami merasa bahwa isterinya kadang-kadang dan sering bersikap kurang menyenangkan suami, dan sikap kurang menyenangkan tersebut menurut suami dikarenakan isterinya merasa juga bekerja atau dapat menghasilkan uang. (Nurhadi, Muflich. 2009. Perubahan Peran Ibu Rumah Tangga Pengaruhnya Terhadap Harmonisasi Keluarga)

Adapun unsur-unsur keberfungsian sosial menurut Skidmore (1994) dalam Edi Suharto (2005:28) adalah kemampuan dalam memenuhi/merespon kebutuhan dasar, menjalankan peranan sosial, serta mengatasi masalah. Akibat keberfungsian sosial dalam keluarga tidak bisa diciptakan maka akan menimbulkan permasalahan yang dapat mengurangi kualitas hidup seseorang, baik dalam berperan, mengatasi masalah maupun dalam pemenuhan kebutuhan.

\section{Disharmoni Keluarga}

Di dalam suatu keluarga pasti memiliki permasalahan-permasalahan yang menyangkut anggota keluarga. Ada kalanya suatu keluarga terjadi disharmoni keluarga. Faktor-faktor penyebab disharmoni keluarga seperti yang diungkapkan oleh Strong, DeVault, dan Cohen (2011) antara lain lingkungan keluarga itu sendiri, konflik suami-isteri, kecemburuan dan pengaruh pekerjaan terhadap keluarga.

Dalam kaitannya dengan buruh perempuan, tak jarang mereka juga mengalami disharmoni keluarga. Disharmoni keluarga dipicu karena faktor ekonomi. Seperti yang kita ketahui, saat ini tuntutan hidup semakin berat, sehingga sudah banyak perempuan yang memiliki peran ganda sebagai seorang isteri/ibu sekaligus pencari nafkah untuk membantu perekonomian keluarga.

Akibatnya timbullah disfungsionalitas sosial dalam keluarga, yaitu suatu kondisi ketidakmampuan anggota keluarga untuk menjalankan peran-peran dan status-status sosialnya dalam keluarga. Disfungsional keluarga merupakan masalah yang disebabkan oleh keberadaan orang-orang dewasa/orang tua yang tidak sehat jiwanya dalam keluarga, gagal menjalankan fungsi pemeliharaan, perlindungan, dan pembimbing bagi anak-anaknya. Adapun salah satu ciri keluarga yang disfungsional menurut Hawari (dalam Yusuf, 2004) adalah orang tua sibuk dan jarang berada di rumah (parent's absence)

\section{Faktor Pendorong Bekerjanya Buruh Perempuan}

Pembangunan saat ini telah memberikan perubahan dalam bidang ekonomi. Perubahan ekonomi telah membuka gerbang setiap orang untuk berlomba-lomba memenuhi kebutuhan hidupnya dengan didukung pendidikan yang baik, dan kesempatan kerja lebih terbuka, sehingga perempuan ikut serta dalam kegiatan ekonomi dan ingin membuktikan bahwa perempuan juga mampu membantu mencari nafkah. Dari wanita yang bekerja $85 \%$ mengajukan kebutuhan ekonomi sebagai motivasi dasar untuk bekerja (Utami Munandar, 1967:54)

Adapun alasan mengapa perempuan mengalokasikan waktunya untuk bekerja (Mardikanto, 1990:75), yaitu :

1. Untuk menambah pendapatan keluarga (family income), terutama jika pendapatan suami atau keluarga relative kecil. 
2. Memiliki berbagai keunggulan (pendidikan, keterampulan, model relasi, dan lain-lain), sehingga merasa lebih efisien untuk meniti karir dibanding jika hanya melakukan pekerjaan rumah tangga.

3. Untuk menunjukkan eksistensinya sebagai manusia (aktualisasi diri) bahwa ia mampu berprestasi di tengah kehidupan keluarga dan masyarakatnya.

4. Untuk memperoleh status atau kekuasaan lebih besar di dalam kehidupan rumah tangganya.

Dilihat dari perspektif konsep diri dasar Staines (1954) dalam Burns (1993:81), yaitu persepsi individu mengenai kemampuan-kemampuannya, status-statusnya, dan peran-perannya di dunia luar bahwa faktor ekonomi yang melatarbelakangi buruh perempuan bekerja lebih didorong oleh keyakinan perempuan yang bekerja merasa mampu menjalankan perannya di luar rumah sebagai pencari nafkah.Walaupun peran sebagai istri dan ibu tidak "membanggakan", tetapi peran sebagai pencari nafkah juga memiliki pengaruh terhadap keluarganya, yaitu meningkatkan perekonomian keluarga. Mereka ingin dianggap sebagai orang yang berpengaruh dan membawa dampak yang besar untuk keluarga.

\section{Konflik-Konflik yang Dihadapi Buruh Perempuan}

Menurut Meyrs (1993) dalam Ella (2003:286-287) bahwa apabila seseorang dihadapkan pada dua tuntutan harapan sesuai dengan perannya yang berbeda dan harus ditampilkan dalam waktu yang bersamaan, maka orang tersebut mengalami konflik. Seseorang perempuan bekerja mengalami konflik peran ganda jika dia merasakan ketegangan dalam memenuhi tuntutan antara rumah tangga dan pekerjaan, semakin mengkonsentrasikan diri pada pekerjaan, maka akan semakin sulit untuk memenuhi tuntutan yang datang dari keluarganya.

Konflik yang dihadapi buruh perempuan adalah jam kerja yang panjang dan tidak teratur. Hal tersebut membuat buruh perempuan lebih banyak menghabiskan waktu di tempat kerja, sehingga suami dan anak kurang mendapatkan kasih sayang, tumbuh kembang anak tak terpantau, suami kurang mendapatkan motivasi, bahkan kebutuhan mereka sulit dipenuhi.

Menurut Sri Kuntari Ludiro (1980) yang dikutip oleh Utami Munandar (1985:57) mengungkapkan bahwa selain waktu menjadi kendala menjalankan peran dalam keluarga, buruh perempuan juga merasakan kesulitan-kesulitan lain, seperti mereka merasa tidak tenang ketika meninggalkan anak mereka sedang sakit atau usia anak masih dini sehingga mempengaruhi konsentrasi dan kualitas kinerja mereka, kekhawatiran yang timbul kepada orang yang mereka percayai untuk mengasuh dan menitipkan anak pergi meninggalkan mereka, serta keterbatasan kondisi fisik yang melemah akibat terkuras saat bekerja dan ketika sampai di rumah harus menjalankan peran sebagai istri maupun ibu.

\section{Dampak Negatif Buruh Perempuan Bekerja}

Kegiatan buruh perempuan di luar rumah akan berdampak negatif pada diri buruh perempuan maupun keluarga. Buruh perempuan dan wanita bekerja lainnya tentu mengalami dampak psikologis pada diri mereka seperti emosi tidak stabil, stress, mudah marah, sering kelelahan dan gangguan kesehatan (Hidayati \& Alteza, 2009:8). Dalam keluarga, apabila anggotanya tidak mampu menjalankan fungsinya yang sesuai dengan peran sosialnya, akan terjadi disorganisasi keluarga, yakni hilangnya komunikasi antar anggota keluarga yang oleh Goode dinamakan empty shell family (dalam Gerungan, 1991:43).

Hasil penelitian Hidayati \& Alteza (2009:8) menunjukkan dampak yang ditimbulkan pada keluarga antara lain anak kesulitan dalam belajar, emosi yang kurang terkontrol, sering terjadi konflik dengan anggota keluarga mengenai cara mendidik anak, anak menjadi manja, keterbatasan waktu untuk berkumpul dengan keluarga, tidak ada waktu untuk memperhatikan anak-anak, interaksi yang 
terjadi dengan suami relatif terbatas dan ini sering berujung pada kesalahpahaman, anak lebih dekat dengan pengasuh, dan gangguan bicara pada anak

Salah satu dampak komunikasi antar anggota keluarga yang tidak efektif menyebabkan kerawanan akan perselisihan di antara anggota keluarga. Penyediaan waktu sangat penting dalam proses komunikasi antar anggota keluarga dan penanaman nilai-nilai kebaikan kepada anggota keluarga melalui sosialisasi.

\section{Definisi Keluarga}

Burgess dkk (1963) dalam Zaidin Ali (2006:5) menyebutkan bahwa (1) keluarga terdiri dari orang-orang yang disatukan oleh ikatan perkawinan, darah, dan ikatan adopsi, (2) para anggota sebuah keluarga biasanya hidup bersama dalam satu rumah tangga atau jika hidup terpisah, mereka tetap menganggap rumah tangga tersebut sebagai rumah mereka, (3) anggota keluarga berinteraksi dan berkomunikasi satu dengan lainnya dalam peran sosial. Keluarga seperti suami dan isteri, ayah dan ibu, anak laki-laki dan anak perempuan, saudara dan saudari, (4) keluarga sama-sama menggunakan kultur yang sama, yaitu kultur yang diambil dari masyarakat dengan beberapa ciri unik tersendiri.

\section{Kedudukan Buruh Perempuan dalam Keluarga}

Kedudukan buruh perempuan memiliki kedudukan yang sangat krusial di dalam keluarga karena buruh perempuan berperan sebagai isteri dan sebagai ibu.Kedua peran tersebut adalah kunci dari kesuksesan di dalam keluarga. Apabila tidak ada kedua peran tersebut dalam keluarga, sistem dalam keluarga akan rusak.

a) Peran sebagai ibu

Begner dalam Sofia Retnowaty Noor (2008) membagi peran ibu menjadi tujuh peran penting, sebagai berikut adalah :

1) Membina keluarga sejahtera sebagai wahana penanaman nilai agama, etik dan moral serta nilai-nilai luhur bangsa, sehingga memiliki integritas kepribadian dan etos kemandirian yang tangguh;

2) Memenuhi kebutuhan anak (perhatian/atensi, kasih sayang, penerimaan/acceptance, perawtaan/care, dan lain-lain);

3) Bersikap bijaksana dengan menciptakan dan memelihara kebahagiaan. Kedamaian dan kesejahteraan yang berkualitas dalam keluarga serta pemahaman atas potensi dan keterbatasan anak;

4) Melaksanakan peran pendamping terhadap anak, baik dalam belajar, bermain dan bergaul, serta menegakkan disiplin dalam rumah, membina kepatuhan dan ketaatan pada aturan keluarga;

5) Mencurahkan kasih sayang namun tidak memanjakan, melaksanakan kondisi yang ketat dan tegas namun tidak percaya atau mengekang anggota keluarga;

6) Berperan sebagai kawan terhadap anak-anaknya, sehingga dapat membantu mencari jalan keluar dari kesulitan yang dialami anak-anaknya;

7) Memotivasi anak dan mendorong untuk meraih prestasi setinggi-tingginya.

b) Peran sebagai isteri

Perempuan yang bekerja mengundang polemik tersendiri di dalam keluarga, terutama dari sisi suami. Masih banyak suami yang tidak mengizinkan perempuan untuk bekerja karena takut suami tidak diurus, urusan rumah terbengkalai, takut karir suami tersaingi, bahkan takut sang istri tidak puas dengan penghasilan suami (Achir, 1985:58)

\section{Fungsi Keluarga}


Akibat dari kendala-kendala yang dialami buruh perempuan juga mempengaruhi fungsi dari keluarga buruh perempuan itu sendiri. Adapun fungsi-fungsi keluarga menurut Horton dan Hunt (1984:274-279), yaitu :

1) Fungsi Pengaturan Seksual, yaitu keluarga berfungsi untuk mengatur dan mengorganisasikan kepuasan keinginan seksual.

2) Fungsi Reproduksi, yaitu keluarga berfungsi sebagai cara memperoleh keturunan.

3) Fungsi Sosialisasi, yaitu keluarga berfungsi sebagai pengarah dan pembentuk kepribadian anak. Selain itu keluarga juga sebagai model bagi anak dalam bersikap dan bertindak.

4) Fungsi Afeksi, yaitu keluarga berfungsi untuk memberikan perhatian dan kasih sayang kepada anggota keluarga.

5) Fungsi Penentuan Status, yaitu keluarga berfungsi sebagai dasar untuk memberi beberapa status sosial kepada anggota keluarga.

6) Fungsi Perlindungan, yaitu keluarga berfungsi memberikan perlindungan secara fisik, psikis dan sosial kepada anggota keluarga.

7) Fungsi Ekonomi, yaitu keluarga berfungsi memberikan pemenuhan kebutuhan ekonomi dan kebutuhan sehari-hari anggota keluarga.

Fungsi pengaturan seksual dan fungsi reproduksi adalah mengatur dan mengorganisasikan kepuasan keinginan seksual serta mendapatkan keturunan. Pada buruh perempuan tentu mengalami kesulitan pada fungsi ini ketika tidak bisa melayani suami dengan baik, bahkan terlalu lelah untuk melakukan fungsi ini karena seharian bekerja. Fungsi sosialisasi ini salah satunya adalah membimbing dan mendidik anak serta mengenalkan nilai-nilai dan norma-norma yanag berlaku di keluarga maupun di masyarakat.Apabila hal ini tidak dapat dilakukan oleh perempuan bekerja yang hampir tidak ada waktu menjalankan peran dan fungsi dari seorang ibu, dapat membahayakan si anak. Si anak akan cenderung melakukan hal-hal negatif. Selain itu, fungsi perlindungan yang harusnya diberikan kepada anggota keluarganya, berupa mental dan moral.Hal ini dapat membentuk kepribadian yang kuat pada anak maupun suami.Fungsi afeksi berhubungan dengan cinta kasih yang menjadi dasar perkawinan dan persamaan pandangan nilai-nilai. Apabila fungsi ini mengalami masalah, tentu akan terjadi perselisihan di antara suami-istri. Perselisihan yang terjadi dapat mempengaruhi perkembangan pribadi anak. Suami-istri yang sibuk berselisih hingga urusan anak terbengkalai. Fungsi penentuan status berhubungan dengan menjalankan peran sesuai status sosial kepada anggota keluarga. Dalam hal ini, buruh perempuan juga mengalami kesulitan melaksanakan peranannya sebagai isteri maupun ibu. Fungsi yang terakhir adalah fungsi ekonomi yang berhubungan pemenuhan ekonomi dan kebutuhan sehari-hari anggota keluarga. Fungsi ini identik dilakukan oleh seorang suami yang berperan sebagai pencari nafkah. Namun, yang dialami buruh perempuan justru kebalikannya. Mereka berperan sebagai pencari nafkah untuk membantu perekonomian keluarga dan pemenuhan kebutuhan sehari-hari, sehingga fungsi ini tentu dapat dilakukan.

\section{Keberfungsian Sosial}

Keberfungsian sosial (social functioning) adalah suatu konsep kunci untuk memahami kesejahteraan sosial, dan merupakan konsep yang penting bagi pekerjaan sosial.Keberfungsian sosial merupakan sebuah konsep pembeda antara profesi pekerjaan sosial dengan profesi lainnya. Pekerjaan sosial adalah profesi pertolongan manusia (The Human Service Profession) yang bertujuan untuk membantu individu, keluarga, dan masyarakat agar mampu menjalankan tugas-tugasnya sesuai dengan perannya sehingga dapat menjalankan keberfungsian sosial dengan baik. Budhi Wibhawa dkk dalam buku Dasar-Dasar Pekerjaan Sosial (2010:21) mengatakan bahwa konsep keberfungsian sosial pada intinya menunjuk pada "kapabilitas" (capabilities) indvidu, keluarga, atau masyarakat dalam menjalankan peran-peran sosial di lingkungannya. Selain itu, keberfungsian sosial juga melibatkan sistem sosial yang terkandung dalam kehidupan masyarakat karena kemampuan individu, keluarga, 
kelompok, dan masyarakat adalah wujud lain dari sistem sosial yang menjadi pendukung dalam interaksi sosial.

Keberfungsian sosial itu sendiri menurut Skidmore dalam Edi Suharto (2005:28) adalah :

"keberfungsian sosial adalah sebagai kemampuan orang (individu, keluarga, kelompok, atau masyarakat) dan sistem sosial (badan/lembaga dan jaringan sosial) dalam memenuhi/merespon kebutuhan dasar, menjalankan peranan sosial, serta menghadapi goncangan dan tekanan (shock and stresses)".

Berdasarkan dampak yang dialami buruh perempuan dalam keluarga tentu dapat mempengaruhi keberfungsian sosial buruh perempuan itu sendiri. Keberfungsian sosial pada buruh perempuan dianggap tidak baik karena terbatas oleh jenis pekerjaan sebagai buruh sektor industri yang tak lepas dari jam kerja yang padat dan tidak teratur. Tentu hal ini akan mempengaruhi bagaimana buruh perempuan berperan dalam keluarga baik sebagai seorang isteri maupun seorang ibu. Di samping itu, ketika buruh perempuan bekerja, kebutuhan dasar anggota keluarga akan terabaikan, mulai kebutuhan fisik, kebutuhan rasa aman, kebutuhan kasih sayang dan sebagainya. Dalam hal mengatasi masalah, buruh perempuan juga kurang waktu untuk berkumpul dan berdiskusi dengan anggota keluarga untuk menyelesaikan masalah yang ada. Komunikasi yang kurang terjalin dengan anggota keluarga menimbulkan ketidakterbukaan buruh perempuan dengan anggota keluarga.

\section{Intervensi Pekerjaan Sosial}

Intervensi pekerja sosial dalam menyelesaikan masalah keberfungsian sosial yang dialami buruh perempuan dalam keluarga adalah social casework. Hal ini karena yang dijadikan klien adalah buruh perempuan. Social casework menurut Perlman (1967) dalam Betty J. Piccard (1983:51) sebagai berikut :

"Social casework is a process used by certain human welfare agencies to help individuals to cope more effectively with their problems in social functioning...."

Dalam menangani permasalahan keberfungsian sosial pada buruh perempuan dalam keluarga, pekerja sosial memiliki peran sebagai enabler. Enabler menurut Zastrow (2010: 70-72) adalah pekerja membantu individu atau kelompok untuk mengartikulasikan kebutuhan mereka, untuk mengklarifikasi dan mengidentifikasi masalah mereka, untuk mengeksplorasi strategi resolusi, untuk memilih dan menerapkan strategi, dan untuk mengembangkan kapasitas mereka untuk berurusan dengan masalah mereka sendiri secara lebih efektif. Adapun metode yang digunakan dengan melakukan konseling keluarga. Tujuan umum konseling keluarga (Perez, 1979), antara lain :

a. Membantu anggota keluarga untuk belajar dan secara emosional menghargai bahwa dinamika kelurga saling bertautan di antara anggota keluarga.

b. Membantu anggota keluarga agar sadar akan kenyataan bila anggota keluarga mengalami problem, maka ini mungkin merupakan dampak dari satu atau lebih persepsi, harapan, dan interaksi dari anggota keluarga lainnya.

c. Bertindak terus menerus dalam konseling/terapi sampai dengan keseimbangan homeostasis dapat tercapai, yang akan menumbuhkan dan meningkatkan keutuhan keluarga.

d. Mengembangkan apresiasi keluarga terhadap dampak relasi parental terhadap anggota keluarga.

\section{PEMBAHASAN}

Perubahan yang terjadi di masyarakat memicu seseorang untuk memperbaiki dan meningkatkan kualitas hidup. Salah satu cara untuk memperbaiki dan meningkatkan kualitas hidup adalah dengan berpartisipasi dalam sektor publik. Tentu hal ini juga dilakukan oleh kaum perempuan 
yang ingin berpartisipasi ke sektor publik dengan berbagai macam motivasi, salah satunya buruh perempuan.

Salah satu faktor pendorong keterlibatan buruh perempuan di sektor publik adalah masalah ekonomi. Masalah ekonomi ini termasuk salah satu alasan mengapa perempuan mengalokasikan waktunya untuk bekerja, yaitu untuk menambah pendapatan keluarga (Mardikanto, 1990:75). Penghasilan suami yang rendah membuat suami tidak mampu menafkahi keluarga dengan baik. Mengingat kebutuhan hidup semakin meningkat, untuk mengurangi beban perekonomian keluarga, buruh perempuan memilih untuk bekerja walau dengan keterbatasan tingkat pendidikan dan keahlian.

Dalam menjalankan kehidupannya, buruh perempuan dihadapkan dengan dua tuntutan peran, yaitu sebagai ibu rumah tangga dan sebagai pencari nafkah, yang mana kedua peran ini harus dilakukan secara bersamaan dan dilakukan secara optimal. Keadaan dengan menjalankan dua peran secara bersamaan membuat buruh perempuan cukup dilematis serta menimbulkan konflik-konflik yang cukup pelik dalam diri buruh perempuan dalam mengoptimalisasikan perannya.

Menurut Sri Kuntari Ludiro (1980) yang dikutip oleh Utami Munandar (1985:57) mengungkapkan bahwa para buruh perempuan merasakan kesulitan-kesulitan seperti waktu, perasaan tidak tenang dan merasa bersalah, pengasuhan, dan kondisi fisik yang lelah. Kondisi seperti itu dikarenakan jenis pekerjaan mereka yang menuntut bekerja selama 8 sampai 9 jam dalam sehari untuk mengejar target produksi. Apabila target produksi tidak dapat dicapai, maka akan mempengaruhi besar kecilnya upah yang didapatkan. Jam kerja yang panjang membuat fisik buruh perempuan kelelahan karena seharian bekerja. Akibatnya buruh perempuan merasa kesulitan dalam mengatur dan mengurusi rumah tangganya. Selama bekerja, tak jarang para buruh perempuan meninggalkan anak mereka yang masih membutuhkan kasih sayang seorang ibu, dan lebih menitipkan anak mereka pada keluarga maupun tetangga.

Konflik-konflik yang dialami buruh perempuan akan menimbulkan dampak psikologis pada diri mereka maupun dampak terhadap keluarga. Dampak psikologis yang timbulkan seperti emosi tidak stabil, stress, mudah marah, sering kelelahan dan gangguan kesehatan (Hidayati \& Alteza, 2009:8). Sedangkan dampak terhadap keluarga akan terjadi disfungsionalitas sosial keluarga, yaitu suatu kondisi ketidakmampuan anggota keluarga untuk menjalankan peran-peran dan status-status sosialnya dalam keluarga. Adapun ciri-ciri keluarga yang disfungsional menurut Hawari (dalam Yusuf, 2004) yang menggambarkan keadaan buruh perempuan dalam keluarga adalah hubungan kedua orang tua tidak baik (poor marriage), hubungan orang tua dengan anak tidak baik (poor parentchild relationship), suasana rumah tangga yang tegang dan tanpa kehangatan (high tension and low warmth), orang tua sibuk dan jarang berada di rumah (parent's absence).

Kondisi buruh perempuan yang telah dikemukakan sebelumnya menunjukkan bahwa keberfungsian sosial mereka belum optimal. Keberfungsian sosial itu sendiri menurut Skidmore (1994) dalam Edi Suharto (2005:28) adalah kemampuan individu, keluarga, kelompok, atau masyarakat dan sistem sosial dalam memenuhi kebutuhan dasar, menjalankan peranan sosial, serta mengatasi masalah.

Dalam menciptakan keberfungsian sosial pada diri buruh perempuan, dibutuhkan peran pekerja sosial. Dalam hal ini pekerja sosial berperan untuk membantu buruh perempuan untuk dapat meningkatkan kemampuan buruh perempuan dalam menjalankan perannya, pemenuhan kebutuhan dasarnya dalam keluarga, memperbaiki relasi buruh perempuan dengan anggota keluarganya, serta mampu mengatasi masalahnya dalam keluarga dengan cara memperbaiki komunikasi di antara anggota keluarga, seperti berkumpul dan saling terbuka di antara anggota keluarga. Selain itu, pihak perusahaan seharusnya memberikan pelayanan konseling kepada karyawannya agar karyawan dapat menyelesaikan masalahnya dan tidak mempengaruhi kinerja pekerjaannya. Yang paling vital adalah kebijakan dari pemerintah maupun perusahaan mengenai jam kerja yang padat perlu dipertimbangkan lagi, khususnya untuk perempuan. Karena selama ini, kebijakan jam kerja banyak dilanggar oleh perusahaan, di mana buruh perempuan diberikan jam kerja tambahan "lembur" untuk mengejar target 
produksi, yang belum tentu juga gaji mereka ditambah melainkan dikurangi apabila ada kesalahan dan tidak mencapai target.

\section{PENUTUP}

Keterlibatan buruh perempuan di sektor publik telah menggeser komitmen sebagai isteri maupun ibu dalam keluarga.Keterlibatan buruh perempuan tidak sedikitnya karena faktor ekonomi. Dalam menjalankan peran ganda, buruh perempuan mengalami konflik peran dan konflik perasaan.

Konflik yang dialami membuat keberfungsian sosial buruh perempuan belum dapat diciptakan, karena tidak sepenuhnya menjalankan peran sebagai isteri maupun ibu, sehingga mempengaruhi kualitas buruh perempuan sebagai individu yang baik. Oleh karena itu, perlu intervensi pekerja sosial dengan buruh perempuan sebagai klien serta menggunakan metode casework untuk mengembalikan dan menciptakan keberfungsian sosial individu.

Merujuk pada hasil penelitian Muflich Nurhadi (2009), jika istri yang bekerja tersebut pendapatannya dapat untuk mencukupi seluruh kebutuhan keluarga, maka disfungsional bagi urusanurusan kerumahtanggaan, ketergantungan ekonomis kepada suaminya menjadi rendah, sikap kemandiriannya (istri) menjadi tinggi, sehingga tingkat harmonisasi keluarga dapat menjadi goyah, meskipun seluruh kebutuhan ekonomi keluarga relatif dapat tercukupi. Sementara itu istri yang bekerja yang pendapatannya hanya cukup untuk memenuhi kebutuhan makan keluarga saja, maka ia akan tetap fungsional bagi pekerjaan-pekerjaan rumahtangga, ketergantungan ekonomisnya kepada suami juga tetap tinggi. Sementara itu sikap kemandiriannya berada dalam kategori rendah, saling ketergatantungan suami-istri tetap tinggi, dan keluarganya nampak berada dalam kategori harmonis.

\section{Daftar Rujukan}

Ali, Zaidin. 2006. Pengantar Keperawatan Keluarga. Jakarta: EGC

Burns R.B. 1993. Konsep Diri. Jakarta: Arcan

Departemen Sosial RI, Direktorat Jenderal Pemberdayaan Sosial, Direktorat Pemberdayaan Keluarga. 2006. Konsultasi dan Advokasi Sosial Keluarga. Jakarta: Direktorat Pemberdayaan Keluarga.

Gerungan, W.A. 1991. Psikologi Sosial. Bandung: Eresco.

Hidayati, Lina Nur \& Alteza, Muniya. 2009. Work-Family Conflict Pada Wanita Bekerja : Studi Tentang Penyebab, Dampak, dan Strategi Coping : Laporan Penelitian.

http://staff.uny.ac.id/sites/default/files/penelitian/Muniya\%20Alteza,\%20SE.,M\%20Si./Work\%20F amily\%20Conflict\%20pada\%20Wanita\%20Bekerja_Studi\%20Tentang\%20Penyebab, $\% 2$ ODampak\%20dan\%20Strategi\%20Coping.pdf Diakses pada 15 Juni 2014 pukul 11.20 WIB

Horton, Paul B dan Chester L. Hunt.1984. Sosiologi Jilid 1 Edisi Keenam.Jakarta : Erlangga.

Mardikanto, Totok. 1990. Wanita dan Keluarga. Surakarta: PT Tri Tunggal Tata

Fajar.

Meyrs, D.G., 1993. Social Psycology, Tokyo : Mc. Graw hill Book Company. Inc.

Munandar, Utami SC. 1985. Emansipasi Dan Peran Gender Wanita Indonesia:

Suatu Tinjauan Psikologis. Jakarta: Universitas Indonesia

Noor, Sofia Retnowaty. 2008. Peran Perempuan dalam Keluarga Islami.http://sofiapsy.staff.ugm.ac.id/files/peran_perempuan_dalam_keluarga_islami. Diakses pada 6 Mei 2014 pukul 14.00 WIB

Nurhadi, Muflich. 2009. Perubahan Peran Ibu Rumah Tangga Pengaruhnya Terhadap Harmonisasi Keluarga, Volume XXI No 2. Surakarta: UNS. Diakses pada 6 Maret 2014 pukul 14.20 WIB

Nurlela, Ella. 2003. Komitmen Kerja dan Konflik Peran Wanita Bekerja.Jurnal Ilmiah Pekerjaan Sosial Vol 2. Bandung: STKS 
Piccard, Betty J. 1983. An Introduction to Social Work. USA: The Dorsey Press

Suharto, Edi. 2005. Membangun Masyarakat Memberdayakan Rakyat. Bandung: Refika Aditama.

Wibhawa, Budhi dkk. 2010. Dasar-Dasar Pekerjaan Sosial. Bandung: Widya Padjadjaran

Zastrow, Charles. 2010. Introduction to Social Work and Social Welfare, 10th Edition Empowering People. Brooks/Cole, Cengage Learning: USA.

http://m.rnw.nl/bahasa-Indonesia/node/137853. Diakses pada tanggal 4 Mei 2014 pukul $19.30 \mathrm{WIB}$ http://jabar.bps.go.id/publikasi_BPS/2013/inkesra2012/files/search/searchtext.xml diakses pada tanggal 1 Oktober 2014 pukul 07.05 WIB

http://jito-um.blogspot.com/2009/05/permasalahan-kemiskinan.html. Diakses pada tanggal 2 Oktober 2014 pukul 17.15 WIB

http://m.hukumonline.com/berita/baca/lt51ca80df50bad/anak-anak-pekerja-butuh-perhatian. Diakses pada tanggal 4 Mei 2014 pukul 20.00 WIB

http://www.benangmerah.net/place/idn/jawa-barat/kabupatensumedang\#dataukpgoiddatasetjumlah-penduduk-15-tahun-ke-atas-yang-bekerja-perkabupaten.com diakses pada tanggal 6 November 2014 pukul 16.10 WIB 